\title{
HORMON ECDYSTERON DARI EKSTRAK DAUN MURBEI, MorUs spp. SEBAGAI MOULTING STIMULAN PADA KEPITING BAKAU
}

\author{
Herlinah, Andi Tenriulo, dan Emma Suryati \\ Balai Penelitian dan Pengembangan Budidaya Air Payau \\ Jl. Makmur Dg. Sitakka No. 129, Maros 90512, Sulawesi Selatan \\ E-mail: hjompa@yahoo.com
}

(Naskah diterima: 4 Februari 2014; Revisi final: 10 Juli 2014; Disetujui publikasi: 10 November 2014)

\begin{abstract}
ABSTRAK
Murbei terbukti mampu mempercepat moulting pada insekta (ulat sutera). Persamaan filum (Arthropoda) antara kepiting dan ulat sutra memungkinkan efek mekanisme kerja ecdysteron $(E C D)$ daun murbei pada fase moulting ulat sutra juga bekerja pada fase moulting kepiting bakau. Penelitian ini bertujuan untuk melakukan isolasi dan identifikasi kandungan $E C D$ pada tanaman murbei. Selanjutnya pemanfaatan ekstrak daun murbei sebagai moulting stimulan pada kepiting bakau. ECD dari daun murbei diperoleh melalui isolasi, pemurnian, serta identifikasi secara spektroskopi antara lain pengukuran panjang gelombang sinar ultra violet dan spektrum infra merah untuk menentukan gugus fungsi. Kandungan ECD pada kepiting dari setiap fase moulting dilakukan melalui ekstraksi pada hemolimp menggunakan pelarut diethyl ether kemudian diukur menggunakan High Performance Liquid Chromatography (HPLC). Hasil penelitian memperlihatkan kandungan ECD pada tanaman murbei Morus spp. diperoleh pada fraksi kedua $(1.058,62 \mathrm{mg} / \mathrm{L})$ dan ketiga $(1.088,4 \mathrm{mg} / \mathrm{L})$. Sedangkan kandungan ecdysteron pada haemolimp yang paling tinggi pada fase sebelum moulting $(4,53 \mathrm{mg} / \mathrm{L})$ dan sesudah moulting (2,52 mg/L). Aplikasi ecdysteron pada kepiting bakau melalui penyuntikan memperlihatkan dosis yang paling optimal pada $100 \mathrm{mg} / \mathrm{L} \mathrm{ECD}$.
\end{abstract}

KATA KUNCl: ecdysteron, murbei, moulting stimulan, kepiting bakau

ABSTRACT: Hormone ecdysterone of mulberry leaves extract, Morus spp. as moulting stimulant on mangrove crabs. By: Herlinah, Andi Tenriulo, and Emma Suryati

Mulberry has been proven to accelerate moulting in insects such as silkworm. Silk worm and mangrove crab belonged to the same phylum and sugested that mulberry have some effect to the moult of crab. This study aimed to isolate and identify the content of ECD on mulberry plants. Further utilization of mulberry leaf extract as a stimulant agent on the mangrove crab moulting. ECD of mulberry leaves was obtained through isolation, purification, and spectroscopic identification include measurement wavelength ultraviolet and infrared spectra to determine the functional groups. The content of ECD at each phase of moulting crabs through solvent extraction using diethyl ether hemolimp then measured using High Performance Liquid Chromatography (HPLC). The results showed that the content of ECD on mulberry plant Morus spp. obtained in the second fraction $(1,058.62 \mathrm{mg} / \mathrm{L})$ and third $(1,088.4 \mathrm{mg} / \mathrm{L})$. While the content of the haemolimp ecdysteron the highest in the phase prior to moulting $(4.53 \mathrm{mg} / \mathrm{L})$ and after moulting $(2.52 \mathrm{mg} / \mathrm{L})$. Ecdysteron application on mangrove crabs carried on through the controlled injection of basin showing the most optimal dose at $100 \mathrm{mg} / \mathrm{L} \mathrm{ECD}$.

KEYWORDS: ecdysteron, mulberry, moulting stimulant, mangrove crabs 


\section{PENDAHULUAN}

Ecdysteron merupakan hormon streoid utama pada arthropoda (termasuk krustase dan serangga) yang memiliki fungsi utama sebagai hormon moulting (penggantian kulit) dan mengontrol pembentukan exoskeleton baru untuk menggantikan exoskeleton yang lama, selain itu, juga mengatur fungsi fisiologi, seperti pertumbuhan, metamorfosis, dan reproduksi. Pada budidaya kepiting, penggantian kulit dapat terjadi secara alami atau dapat diinduksi melalui rangsangan dan penambahan hormon ini (Lafont et al., 2003; Gunamalai et al., 2003).

Beberapa tumbuhan yang diketahui mengandung ecdysteron antara lain: tanaman bayam yang mengandung ECD pada semua bagian tanamannya, demikian juga dengan Asparagus, murbei, krokot, dan paku-pakuan yang banyak terdapat di dataran tinggi termasuk tanaman pakis raja atau yang dikenal dengan (Cycas revoluta) Thum (Suryati et al., 2013). Murbei, Morus spp. dikenal juga sebagai tumbuhan sutra karena dapat dijadikan tempat hidup dan pakan ulat sutra, Bombyx mori (Sanchez, 2000). Murbei mengandung banyak senyawa kimia seperti: ecdysteron, inokosterone, lupeol, $\beta$-sitosterol, rutin, moracetin, scopoletin, benzaldehida, eugenol, linalol, benzyl alkohol, butylamine, aseton, kholine, dan quercetin (Kim et al., 2000). Murbei telah terbukti mampu mempercepat moulting pada insekta (ulat sutera). Persamaan filum (Arthropoda) antara kepiting dan ulat sutra memungkinkan efek mekanisme kerja ecdysteron daun murbei pada fase moulting ulat sutra juga bekerja pada fase moulting kepiting bakau. Hormon ecdysteron yang ada, biasanya diperoleh melalui isolasi dari beberapa spesies krustase yang harganya relatif mahal dan sulit diperoleh sehingga perlu dicari alternatif lain untuk mengantisipasi hal tersebut yaitu menggunakan ecdysteron yang berasal dari tumbuhan (Harborn, 1973).

Ganti kulit (moulting/ecdysis) adalah proses yang sangat penting dalam siklus hidup anthropoda (termasuk dekapoda) sebab pelepasan cangkang adalah suatu keharusan untuk proses pertumbuhan dan metamorfosis (Dorrington, 1979; Fattah, 1998), Karena pentingnya mekanisme moulting untuk pertumbuhan dan produksi kepiting maka perlu inovasi teknologi dalam hal rekayasa fisiologi moulting (hormon ecdysteron). Rekayasa fi- siologi dibutuhkan untuk mempercepat fase moulting dan mendapatkan waktu moulting yang bersamaan. Penelitian ini bertujuan untuk mengisolasi dan mengidentifikasi kandungan ecdysteron pada tanaman murbei dan menentukan dosis ekstrak daun murbei yang dapat memacu terjadinya pergantian kulit pada kepiting bakau. Informasi yang didapatkan akan sangat menunjang "Sistem Inovasi Teknologi Nasional" dalam rangka pengembangan teknologi budidaya kepiting bakau terutama dalam hal merekayasa fisiologi hormonal untuk mempercepat moulting khususnya dalam produksi kepiting cangkang lunak (soft cell crab) skala massal.

\section{METODE PENELITIAN}

Penelitian terdiri atas tiga tahapan utama yaitu: 1) isolasi ecdysteron, 2) identifikasi kandungan ecdysteron, dan 3) penentuan dosis ekstrak daun murbei yang dapat memacu terjadinya pergantian kulit pada kepiting bakau. Penelitian isolasi dan identifikasi ecdysteron dilakukan di Laboratorium Bioteknologi Balai Penelitian dan Pengembangan Budidaya Air Payau (BPPBAP) Maros dan analisis sampel di beberapa laboratorium yaitu: Laboratorium Kualitas Air BPPBAP Maros untuk uji Ultraviolet Visible (UV-VIS), Laboratorium Terpadu Kimia UNHAS untuk uji Fourier Transform Infra Red (FTIR), Laboratorium Bioteknologi Jakarta dan Laboratorium Bio Farmaka UNHAS untuk uji kandungan ecdysteron.

Tanaman murbei (Morus alba) dikumpulkan dari Balai Penelitian dan Pengembangan Sutra Alam Instalasi Perkebunan murbei di Bilibili, Kabupaten Gowa. Identifikasi nama, genus, spesies dilakukan di laboratorium menggunakan buku kunci (Steenis, 1981). Tanaman murbei dikoleksi dalam keadaan segar, kemudian daunnya dikeringanginkan pada suhu $27^{\circ} \mathrm{C}-30^{\circ} \mathrm{C}$.

\section{Isolasi Ecdysteron dari Daun Murbei}

Isolasi dan pemurnian ecdysteron daun murbei dilakukan dengan cara maserasi, daun murbei kering ditimbang kurang lebih 300 $500 \mathrm{~g}$ dihaluskan dengan blender kemudian diekstraksi menggunakan pelarut metanol $80 \%$ dengan lama perendaman $3 \times 24$ jam untuk mendapatkan ekstrak kasar. Ekstrak kasar yang diperoleh dipekatkan menggunakan rotary evaporator hingga kering berwarna hijau kehitaman (Harborn, 1973). 


\section{Fraksinasi}

Ekstrak kental ditambahkan dengan aseton tiga kali, yaitu sebanyak 50, 100, dan 200 $\mathrm{mL}$. Selanjutnya ekstrak dipisahkan dengan menggunakan corong pisah berdasarkan kepolaran pelarut. Fraksi yang diperoleh dikisatkan kembali dengan menggunakan rotary evaporator hingga setengah volume. Kemudian ekstrak dilarutkan dengan metanol $50 \%$ sebanyak $100 \mathrm{~mL}$ dan diekstraksi cair dengan n-heksan tiga kali sebanyak $50 \mathrm{~mL}$. Fraksi metanol yang diperoleh ditambahkan alumina sebanyak $140 \mathrm{~g}$ kemudian dikisatkan dengan menggunakan rotary evaporator hingga diperoleh ekstrak kering berupa serbuk berwarna coklat.

Ekstrak kering dielusi dengan campuran pelarut diklorometan dan etanol dengan menaikkan tingkat kepolarannya yaitu dengan gradien 100:0 (F-1), 95:5 (F-2), 90:10 (F-3), dan 80:20 (F-4). Hingga diperoleh empat fraksi yang berbeda kepolarannya. Keempat fraksi dikisatkan hingga kering sehingga diperoleh pasta berwarna hijau tua.

\section{Identifikasi Kandungan Ecdysteron}

Setelah pelarut diuapkan, residu yang diperoleh dilarutkan dengan metanol HPLC masing-masing sebanyak $10 \mathrm{~mL}$. Keempat fraksi dimurnikan dengan metode ekstraksi fase padat menggunakan Seppak $\mathrm{C}_{18}$ selanjutnya disaring dengan filter Polytetrafluoroethylene (PTFE). Selanjutnya keempat fraksi diuji kemurniannya melalui HPLC dengan menggunakan detektor photodiode-array (PDA) yang mengacu pada Munson (1984). Selain uji kromatografi dengan HPLC juga dilakukan pengukuran Ultraviolet Visible (UV-Vis) dan spektrum infra merah atau Fourier Transform Infra Red (FT-IR).

\section{Ekstraksi ECD pada Hemolimph Kepiting}

Hewan uji yang digunakan adalah kepiting bakau yang berada dalam masa pertumbuhan dengan ukuran lebar karapas bervariasi antara 7-10 cm dan bobot 55-100 g. Setiap kepiting uji ditimbang bobot dan diukur lebar karapasnya untuk menentukan tingkat kegemukan (faktor kondisi) dengan menggunakan formula Effendie (1997), yaitu:

$$
K=\frac{W}{L^{3}} \times 100
$$

di mana:

$\mathrm{K}=$ Faktor kondisi

$\mathrm{W}=$ Bobot $(\mathrm{g})$

$\mathrm{L}=$ Panjang karapas $(\mathrm{mm})$

Pengukuran kandungan ecdysteron pada setiap fase moulting (intermolt, premolt, molt, dan post molt) dilakukan sebagai acuan untuk menentukan kadar haemolimp yang ada secara alami di dalam tubuh kepiting. Pengambilan hemolimph kepiting bakau sebanyak \pm 1 $\mathrm{mL}$. Hemolimp diambil pada pangkal kaki jalan ke-5 menggunakan syringe $1 \mathrm{~mL}$ yang sebelumnya telah dibilas dengan anti koagulan. Hemolimp kemudian diekstraksi menggunakan pelarut diethyl ether, dikocok menggunakan vortex selama 30 detik, dipisahkan dan diulangi sebanyak tiga kali. Hemolimp dikumpulkan lalu dikisatkan hingga kering, residu yang diperoleh dilarutkan dengan pelarut metanol dan diukur menggunakan HPLC dengan kolom $\mathrm{C}_{18}$ dengan fasa terbalik, dan fasa gerak campuran metanol dengan air dengan perbandingan 85:15 yang dideteksi dengan spektrum ultra violet (UV) pada panjang gelombang 366 nm (Quinitio, 1991).

\section{Aplikasi Pemberian Ecdysteron pada Kepiting}

Aplikasi pemberian ecdysteron pada kepiting dilakukan beberapa kali tahapan uji coba baik di bak terkontrol maupun di tambak. Tahap demi tahap merupakan perbaikan metode melalui uji coba dosis dan perbandingannya dengan pemicu moulting lainnya baik yang bersifat hormonal (ekstrak herbal lain) maupun secara konvensional (melalui pemotongan capit dan pemberian pakan rucah biasa tanpa perlakuan) (Herlinah et al., 2012).

Ekstrak murbei yang diperoleh dilakukan pengenceran berdasarkan estimasi dari bobot basah dan bobot kering sampel daun murbei yang diekstraksi hingga dilakukan pengenceran 40x dari ekstrak murni yang dihasilkan. Ekstrak murbei yang diperoleh mengandung ecdysteron sebanyak 2.664 $\mathrm{mg} / \mathrm{L}$ setara dengan $500 \mathrm{~g}$ bobot segar. Aplikasinya dilakukan melalui pengenceran menggunakan aquadest dari larutan stok. Setelah dilakukan beberapa kali uji coba dan perbaikan metode dan perhitungan berdasarkan hasil uji kromatogram di HPLC, akhirnya ditentukan dosis 100, 125, dan $150 \mathrm{mg} / \mathrm{L}$ (Herlinah et al., 2013; 2014). Aplikasi pada kepiting dilakukan melalui penyuntikan. Pemberian eks- 
trak murbei disesuaikan dengan kandungan ecdysteron yang terukur dari setiap fase moulting (intermolt, premolt, molt, dan post molt), dilakukan melalui penyuntikan pada pangkal kaki jalan ke-5 kepiting bakau.

Wadah pengujian berupa keranjang plastik (crab box) berukuran panjang, lebar, dan tinggi masing-masing $15 \mathrm{~cm} \times 18,5 \mathrm{~cm} \times 20$ $\mathrm{cm}$. Keranjang dilengkapi tutup untuk mencegah keluarnya kepiting dari wadah pemeliharaan. Pengujian ekstrak yang dihasilkan melalui beberapa kali pengujian aplikasi dosis penyuntikan baik di bak maupun di tambak (Herlinah et al., 2012; 2013). Kepiting diberi pakan segar (ikan rucah) sebanyak 5\% dari bobot badan per hari (Fujaya, 2008) dengan frekuensi pemberian pakan sekali dalam sehari secara ad libitum.

Pengamatan dilakukan setiap hari (pagisiang-sore-malam) untuk melihat apakah ada kepiting yang mengalami moulting setelah dilakukan penyuntikan. Sesaat setelah moulting, kondisi kulit kepiting masih sangat lunak, dengan kondisi inilah yang dipanen sebagai kepiting lunak. Pengamatan kepiting moulting dilakukan secara ketat setiap hari hingga empat kali karena kepiting yang terlambat dipanen/diangkat (lebih dari satu jam) cangkangnya akan segera mengeras.

Persentase moulting dihitung berdasarkan jumlah kepiting yang moulting dibagi dengan jumlah kepiting yang diberi perlakuan dikali 100\%. Masa laten moulting adalah waktu yang dibutuhkan sejak perlakuan ekstrak murbei hingga terjadi moulting pada kepiting yang diuji. Mortalitas dihitung dengan membandingkan jumlah kepiting yang mati dibagi dengan jumlah kepiting yang diberi perlakuan dikali $100 \%$.

\section{HASIL DAN BAHASAN}

\section{Isolasi dan Pemisahan Ecdysteron pada Daun Murbei}

Ekstrak kasar ecdysteron dari daun murbei diperoleh melalui maserasi menggunakan pelarut metanol $80 \%$ dengan lama perendaman $3 \times 24$ jam. Hasil fraksinasi menggunakan pelarut dengan perbandingan campuran pelarut diklorometan dan etanol dengan menaikkan tingkat kepolarannya yaitu dengan gradien F-1 (100:0), F-2 (95:5), F-3 (90:10), dan F-4 (80:20). Kromatogram dari standar ecdysteron (ECD) dan ECD dari daun murbei dapat dilihat pada Gambar 1 dan 2.

\section{Uji Kemurnian ECD dari Daun Murbei}

Kemurnian ecdysteron yang diperoleh serta standar ECD diuji menggunakan HPLC dengan larutan pembawa campuran metanol dan air dengan perbandingan 80:20. Standar ecdysteron memiliki waktu retensi 1,6 menit; sedangkan sampel tanaman F-1-F-4 berturutturut yaitu 1,823 menit; 1,763 menit; 1,650 menit; dan 1,61 8 menit (Gambar 1 dan 2). Dari hasil tersebut didapatkan bahwa fraksi-3 dan fraksi-4 (sampel M-3 dan M-4) yang paling mendekati standar. Hal ini menunjukkan bahwa hormon ecdysteroid berhasil diisolasi dari daun murbei. Hasil ini berbeda dengan penelitian isolasi ecdysteroid pada pakis dan bayam (Fujaya et al., 2008) yang menemukan bahwa yang memiliki waktu retensi yang menyerupai standar adalah pada fraksi- 1 dan fraksi-2.

Selanjutnya dilakukan pengukuran ECD pada ekstrak murbei berdasarkan pengukuran luas area pada kromatogram menggunakan standar 20-hydroxyecdysone, memperlihatkan gambar kurva kalibrasi seperti pada Gambar 3. Untuk menentukan jumlah ECD yang terkandung di dalam daun murbei, dibutuhkan konversi area dari standar ecdysteron dari luas area sampel yang dianalisis dengan nilai regresi $y=5358,5 x+96721$ dengan $R^{2}=$ 0,999 .

Hasil uji kemurnian ecdysteron dari daun murbei memperlihatkan adanya banyak puncak (Gambar 2) selain pada waktu retensi 1,6 menit; hal ini disebabkan karena adanya pengotor dari senyawa lain pada saat isolasi dan fraksinasi menggunakan kolom kromatografi, sehingga pemisahan kurang sempurna dan masih membawa senyawa-senyawa lain yang terdapat di dalam daun murbei walaupun dalam konsentrasi yang sangat kecil, sehingga dapat diabaikan dalam penggunaannya. Untuk itu, perlu dilakukan pemurnian yang lebih baik agar diperoleh ecdysteron yang lebih murni. Namun demikian ekstrak ECD yang dihasilkan masih dapat digunakan untuk stimulasi moulting pada kepiting.

Kandungan ecdysteron pada daun murbei yang paling tinggi terdapat pada fraksi-3 yakni $1.088,4 \mathrm{mg} / \mathrm{L}$ dan yang paling sedikit pada fraksi-1 (33,29 mg/L) (Gambar 4). Sehingga selanjutnya penggunaan isolat ECD yang dapat digunakan untuk aplikasi stimulasi moulting pada kepiting yakni ekstrak yang berasal dari fraksi-3, demikian pula dengan 


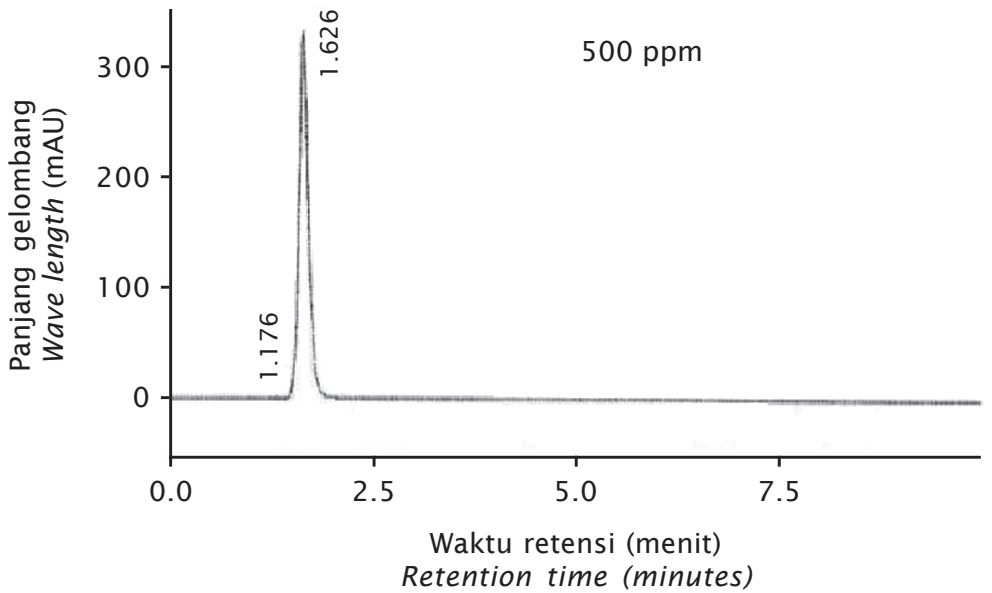

Gambar 1. Kromatogram dari standar ecdysteron

Figure 1. Chromatograms of standard ecdysteron
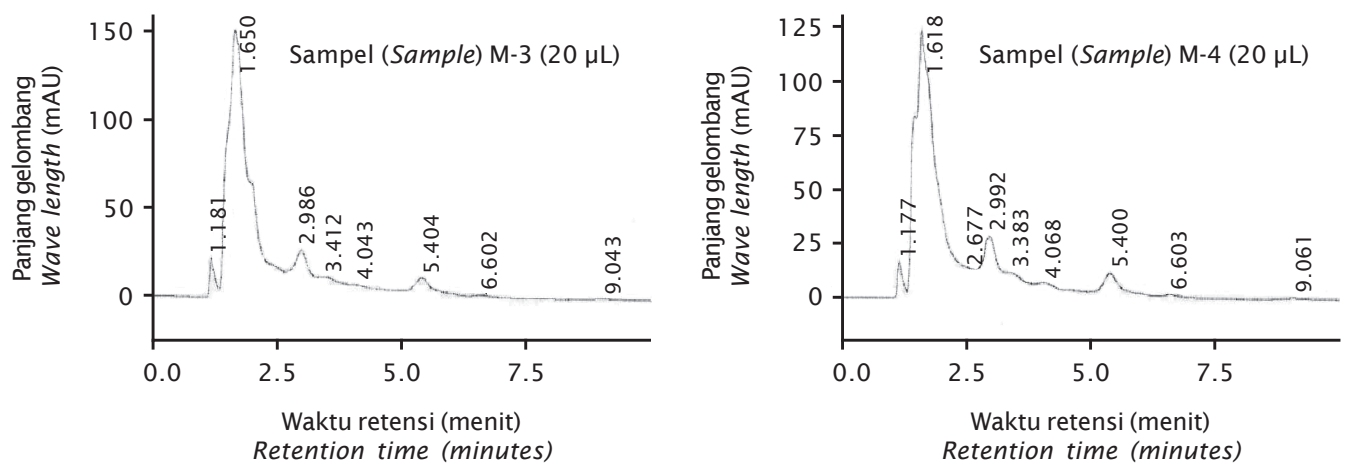

Gambar 2. Kromatogram ecdysteron dari ekstrak murbei fraksi-3 (M-3) dan fraksi-4 (M-4)

Figure 2. Ecdysteron chromatogram of mulberry extract fraction-3 (M-3) and fraction-4 (M-4)

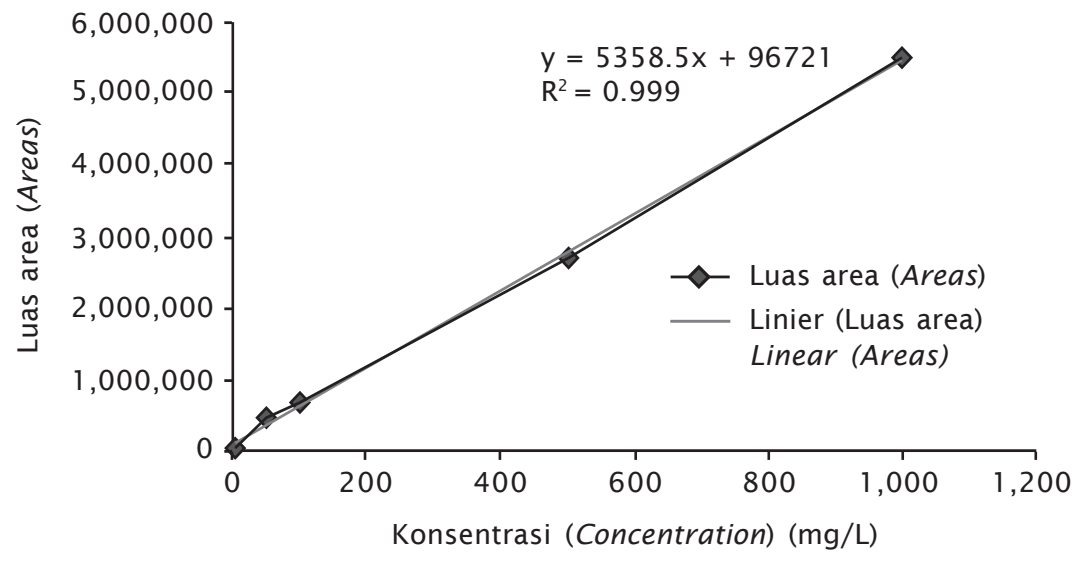

Gambar 3. Kurva kalibrasi ecdysteron

Figure 3. Calibation curve ecdysteron 


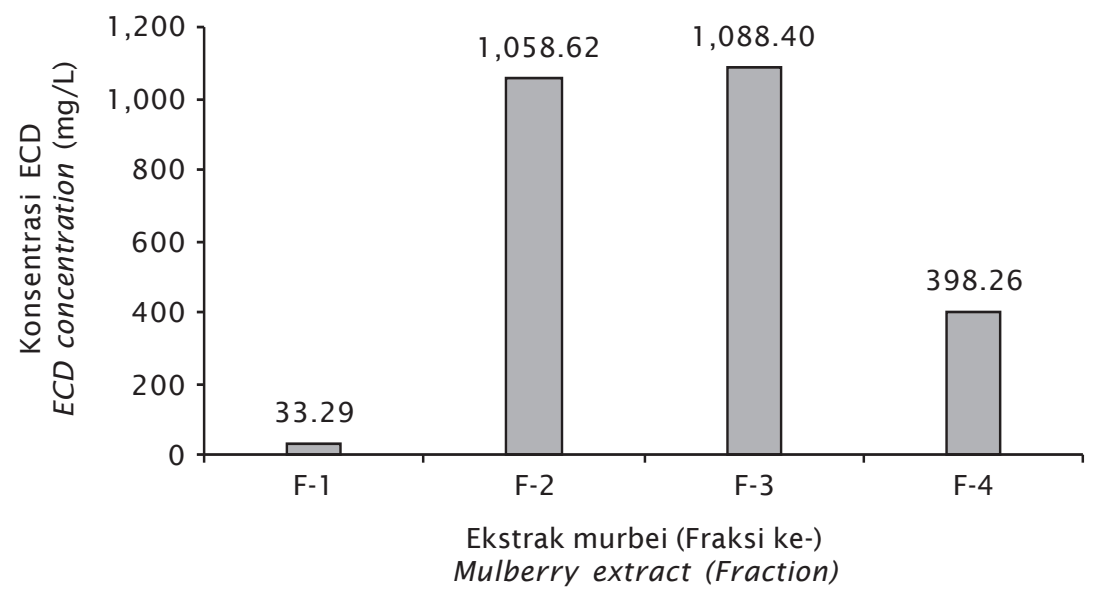

Gambar 4. Kandungan ecdysteron pada daun murbei hasil fraksinasi

Figure 4. The content ecdysteron on mulberry leaves fractionation results

identifikasi dan penentuan struktur dan gugus fungsi dari ECD yang diperoleh. Pada penelitian ini, ekstrak yang digunakan untuk injeksi hormon pada kepiting juga adalah hasil fraksi-3 karena dianggap memiliki kandungan ecdysteron tertinggi.

\section{Identifikasi ECD dari Daun Murbei}

\section{Pengukuran Panjang Gelombang UV-Vis dan FT-IR}

Hasil pengukuran panjang gelombang UVVIS isolat ecdysteron pada ekstrak murbei, memperlihatkan ada dua puncak yang dominan, hal ini memberikan gambaran bahwa se- nyawa tersebut memiliki dua ikatan rangkap yang terkonjugasi. Gambar spektrum UV-VIS dapat dilihat pada Gambar 5.

Spektrum infra merah merupakan spektrum yang menunjukkan banyak puncak absorpsi pada frekuensi yang karakteristik. Untuk setiap ikatan kimia yang berbeda seperti $\mathrm{C}-\mathrm{C}, \mathrm{C}=\mathrm{C}, \mathrm{C}=-\mathrm{O}, \mathrm{C}=\mathrm{O}, \mathrm{O}=\mathrm{H}$ dan sebagainya mempunyai frekuensi vibrasi yang berbeda. Untuk mengidentifikasi senyawa yang belum diketahui perlu dibandingkan dengan spektrum standar yang dibuat pada kondisi sama (Munson, 1984).

Spektrum sampel ekstrak murbei sangat mirip dengan 20-hydroxyecdisone yang di-

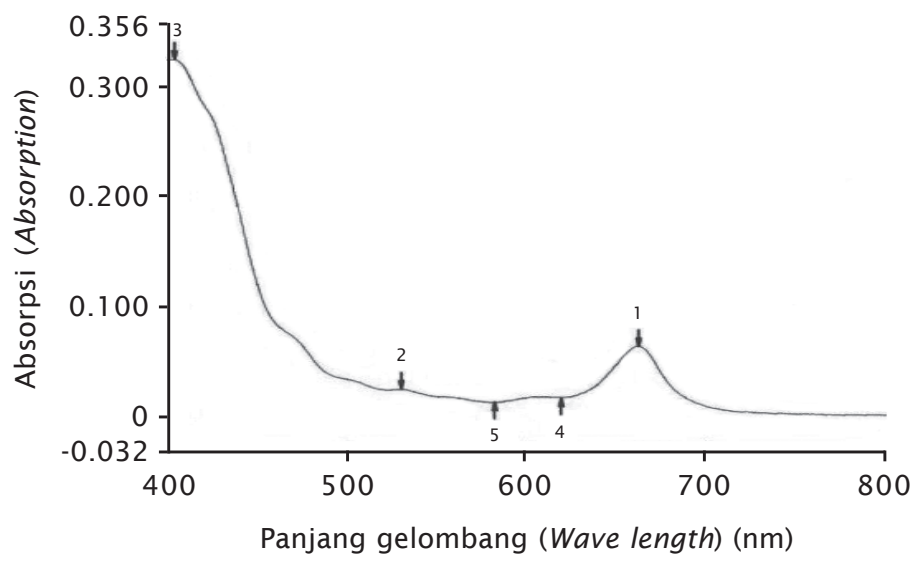

Gambar 5. Spektrum UV-VIS ECD dari ekstrak murbei

Figure 5. UV-VIS spectrum of ECD mulberry extract 
gunakan sebagai standar, ditandai dengan puncak yang melebar pada $3.500-3.300 \mathrm{~cm}^{-1}$ yang menunjukkan adanya gugus fungsi $\mathrm{OH}$, dan pada $1.667 \mathrm{~cm}^{-1}$ yang menunjukkan gugus $\mathrm{C}=\mathrm{C}$ (Gambar 6 ). Hal ini sejalan dengan yang telah dilaporkan oleh Louden et al. (2001) bahwa terdapat serapan yang kuat pada 1.667 $\mathrm{cm}^{-1}$ dan $1.630 \mathrm{~cm}^{-1}$ pada spektrum fitoecdistreroid I4cz-hydroxy-7-en-6-one moiety. Pada senyawa ecdysteron yang diisolasi dari Lhycnis flos - cuculi juga diperoleh ada serapan yang kuat pada $1.667 \mathrm{~cm}^{-1}$ dan $1.642 \mathrm{~cm}^{-1}$.

\section{Ekstraksi ECD pada Hemolimp Kepiting}

Hasil pengukuran ECD pada fase pergantian kulit pada kepiting memperlihatkan kandungan ECD yang tertinggi pada fase sebelum moulting dan fase sesudah moulting dan yang terendah pada saat moulting (Gambar 7), hal ini memperlihatkan bahwa kepiting memerlukan ECD lebih tinggi pada saat sebelum moulting sehingga fenomena ini dapat dijadikan acuan untuk memberikan stimulan pada kepiting agar dapat moulting secara terkontrol.

Kandungan ecdysteron tertinggi dari tiap fase moulting kepiting uji terdapat pada fase premoulting, terendah pada fase moulting dan konsentrasi kembali naik pada fase postmoulting. Hal ini sesuai dengan yang telah dihasilkan oleh (Fujaya et al., 2008; Gimenez et al., 2001; Dooley et al., 2002). Pada fase premoulting, konsentrasi ecdysteron sebesar 175,2 mg/L, fase moulting sebesar 40,76 $\mathrm{mg} / \mathrm{L}$, dan pada fase postmoulting sebesar $50,32 \mathrm{mg} / \mathrm{L}$. Nilai tersebut diperoleh dari perhitungan luas area dari hasil uji kromatogram dengan faktor pengenceran pada saat ekstraksi hormon.
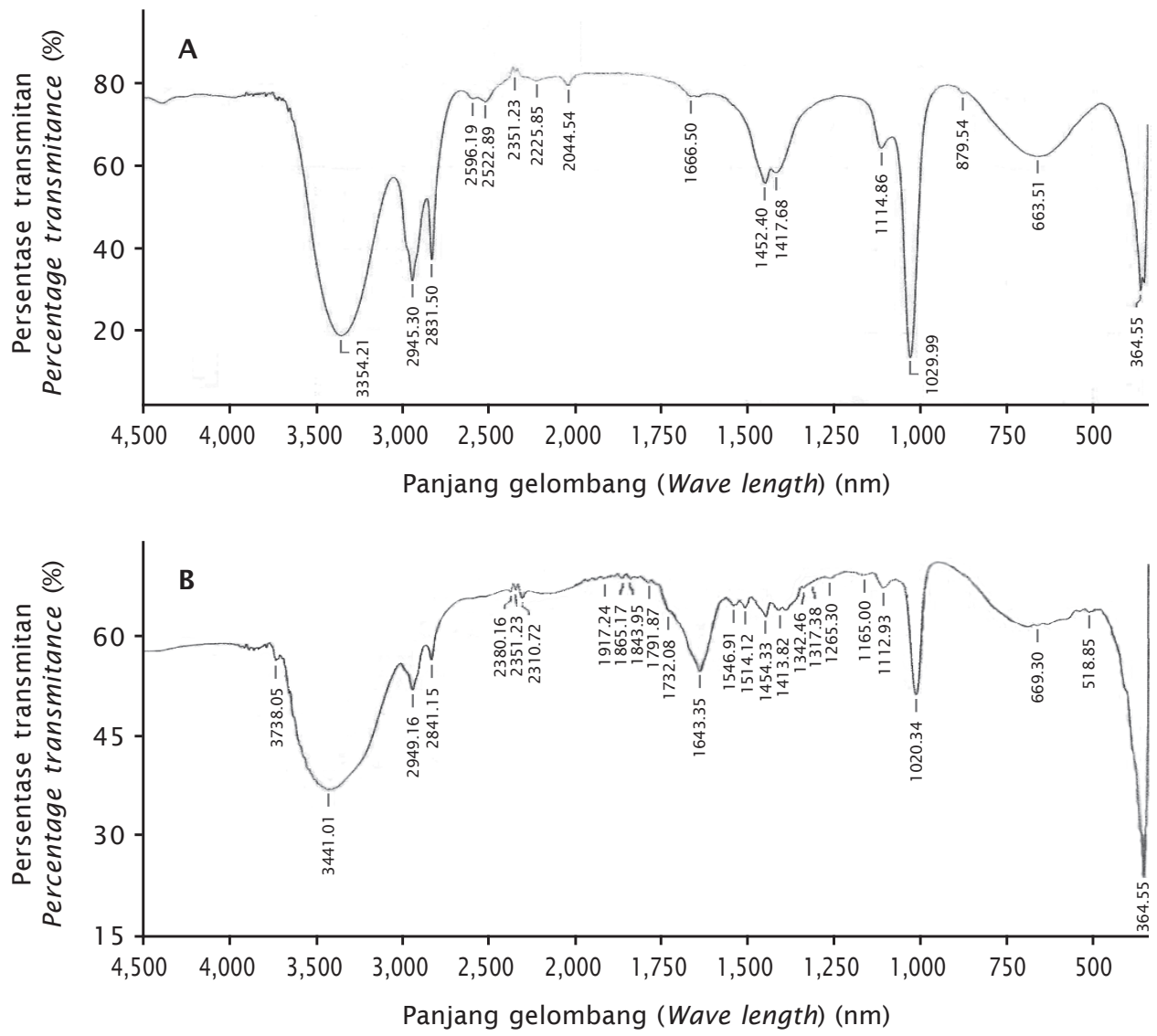

Gambar 6. Spektrum FT-IR dari ECD daun murbei (A) dan standar 20-hydroxyecdisone (B)

Figure 6. FT-IR spectra of ECD mulberry leaves $(A)$ and 20-hydroxyecdisone standart (B) 


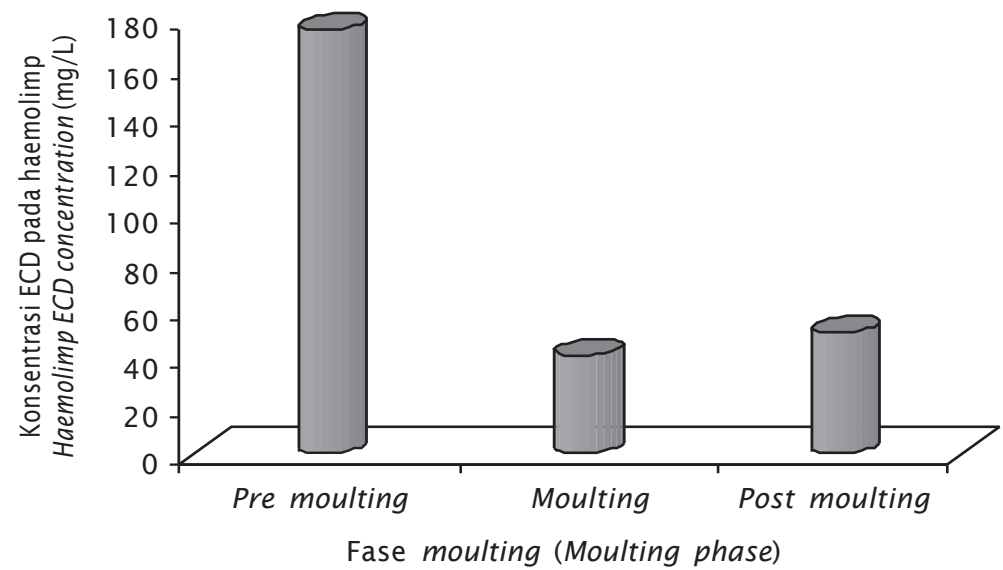

Gambar 7. Konsentrasi ecdysteron pada setiap fase moulting kepiting bakau

Figure 7. Ecdysteron concentration in each phase of the mangrove crab moulting

\section{Aplikasi Pemberian Ecdysteron pada Kepiting}

Pemberian ECD dari daun murbei pada kepiting sebagai moulting stimulan memperlihatkan pemberian ECD dengan konsentrasi $100 \mathrm{mg} / \mathrm{L}$ menghasilkan moulting sebanyak $50 \%$, sedangkan pada kontrol dan konsentrasi $125 \mathrm{mg} / \mathrm{L}$ dan $150 \mathrm{mg} / \mathrm{L}$ hanya menghasilkan 33,3\% saja (Herlinah et al., 2014). Hal ini disebabkan karena kebutuhan ECD untuk stimulasi moulting cukup $100 \mathrm{mg} / \mathrm{L}$ saja dan kemungkinan lebih rendah dari konsentrasi tersebut, karena di dalam kepitingnya sendiri sudah memiliki ECD yang dapat digunakan untuk memacu moulting. Hal ini juga ditunjang oleh hasil yang diperoleh dari beberapa peneliti antara lain Gunamalai et al. (2003). Ecdysterone, sesuai namanya merupakan steroid tulang belakang (steroid backbone) dan sangat berkaitan dengan proses moulting atau yang biasa dikenal dengan ecdysis. Manfaat dari hormon ini selain sebagai hormon moulting juga dapat meningkatkan sintasan karena memberi efek positif terhadap proses metabolisme karbohidrat, lemak, protein, dan tulang (Anonim, 2014).

Secara alami pada kepiting sudah terdapat hormon ecdysteron, sehingga pemberian hormon melalui sistem injeksi didasarkan pada kandungan ecdysteron dan kebutuhan hormon kepiting tersebut pada fase tertentu (Gambar 7). Hormon yang tidak mencukupi maupun pemberian hormon yang berlebih tidak akan termanfaatkan dengan baik.

Masih rendahnya persentase moulting kepiting bakau hasil injeksi dengan ecdysteron murbei yang dihasilkan diduga akibat belum tepatnya dosis hormon yang diaplikasikan. Penentuan dosis yang tepat sangat penting untuk mendapatkan hasil yang optimal (Gambar 8). Hal ini sebagaimana yang dijelaskan oleh Turner \& Bagnara (1998) dalam Fujaya et al. (2012) mengemukakan bahwa hormon dilepaskan pada saat yang tepat dalam jumlah yang wajar pada organisme normal. Kesalahan dalam pemilihan waktu, serta jumlah yang kurang atau lebih akan menimbulkan konsekuensi yang hebat terhadap organisme. Secara spesifik, Dorrington (1979) menjelaskan bahwa konsentrasi hormon yang tinggi menyebabkan produksi reseptor hormon tersebut menjadi terhambat dan kemampuan reseptor sel sasaran dalam mengikat hormon menurun. Reseptor adalah suatu perangkat biologi dalam tubuh yang bertugas mengenali kode yang dibawa oleh suatu hormon. Bila kinerja reseptor menurun maka pembentukan produk baru seperti protein akan terhambat pula. Akibatnya, pertumbuhan dan moulting akan terhambat.

Proses pergantian kulit atau moulting merupakan suatu fenomena yang mutlak terjadi pada krustase termasuk kepiting bakau. $\mathrm{Na-}$ mun peristiwa ini tidak berlangsung dalam waktu dan jumlah yang sama dikarenakan 


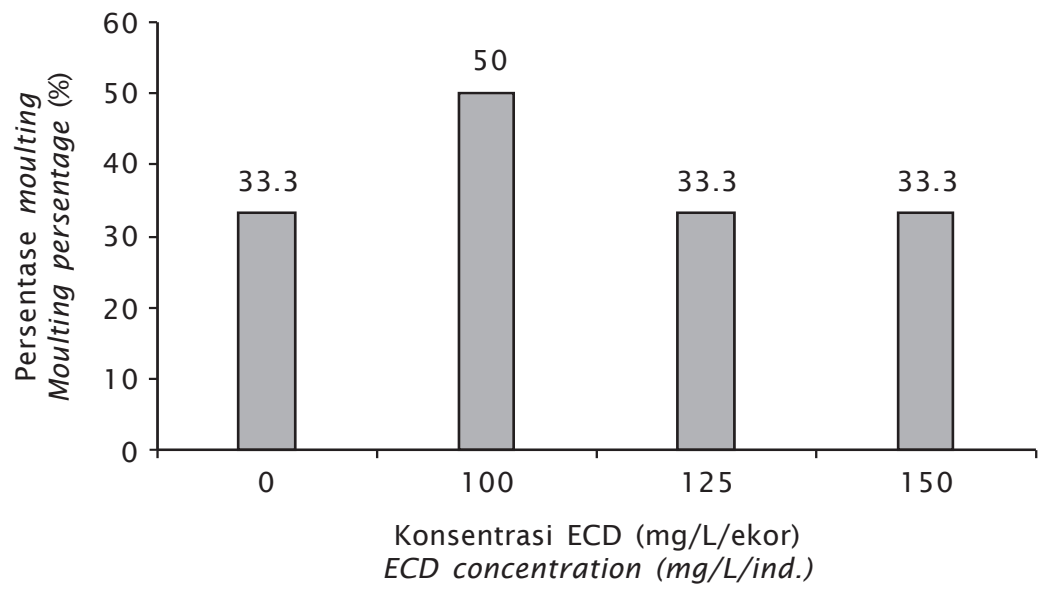

Gambar 8. Persentase moulting pada kepiting menggunakan ECD dari daun murbei (Sumber: Herlinah et al., 2014)

Figure 8. Percentage of moulting in crabs using ECD of mulberry leaves (Source: Herlinah et al., 2014)

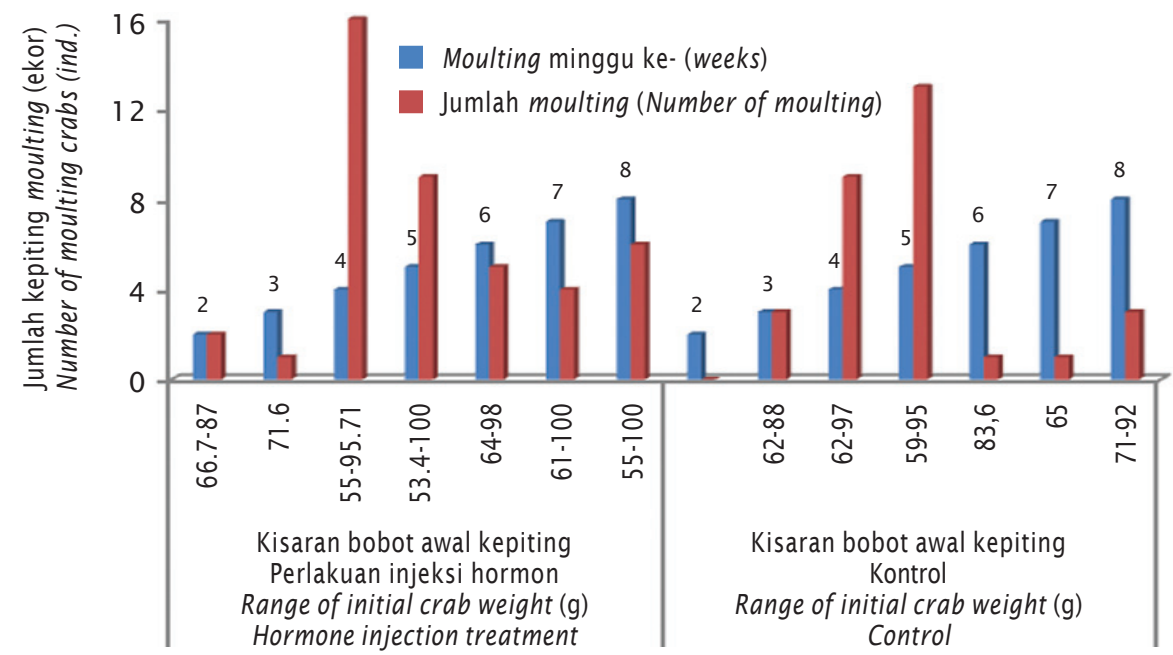

Gambar 9. Hubungan antara perlakuan injeksi hormon dengan bobot awal dan kecepatan moulting kepiting

Figure 9. Hormone injection relation on initial weight and moulting rate of crabs

adanya perbedaan mekanisme fisiologis yang dipengaruhi faktor internal dan eksternal masing-masing spesies. Dalam kondisi normal, kepiting muda tentunya akan memiliki kemungkinan yang lebih besar dan sering untuk moulting dibanding kepiting yang besar ataupun yang telah mencapai kematangan meskipun tidak terlepas dari siklus hormonal (proses fisiologis) yang ada terjadi di dalam tubuh kepiting tersebut. Namun berdasarkan
Gambar 9, menunjukkan bahwa ukuran kepiting uji yang digunakan tidak berpengaruh terhadap kecepatan moulting, hal ini terlihat oleh adanya variasi bobot awal kepiting yang moulting pada minggu kedua hingga minggu kedelapan. Sehingga dapat diyakini bahwa, injeksi hormon yang diberikan cukup menunjukkan efektivitas yang baik terhadap kecepatan moulting dan persentase moulting kepiting. 


\section{KESIMPULAN}

Tanaman murbei Morus spp. mengandung Ecdysteron. Kandungan ECD tanaman murbei Morus spp. yang tertinggi digunakan untuk injeksi hormon pada kepiting berasal dari hasil fraksi ketiga dengan konsentrasi 1.088,4 $\mathrm{mg} / \mathrm{L}$. Kandungan ecdysteron pada haemolimp yang paling tinggi pada fase sebelum moulting $(175,20 \mathrm{mg} / \mathrm{L})$ dan yang paling rendah yaitu pada saat moulting $(40,76 \mathrm{mg} / \mathrm{L})$. Kecepatan moulting tidak dipengaruhi oleh ukuran kepiting uji yang digunakan namun merupakan pengaruh dari injeksi hormon yang menunjukkan efektivitas yang baik terhadap kecepatan moulting dan persentase moulting kepiting.

\section{SARAN}

Perbaikan dan penentuan dosis ekstrak murbei yang tepat dan sesuai untuk pemicu moulting kepiting bakau perlu terus dilakukan dan dikembangkan karena memiliki tren yang berbeda dengan ekstrak herbal yang dihasilkan sebelumnya.

\section{UCAPAN TERIMA KASIH}

Terima kasih disampaikan kepada Bapak Drs. Gunarto, M.Sc., Aan Fibro Widodo S.Si., Fauziyah Ahmad, S.Si., dan Muhammad Syakaria, S.Pi. yang telah mendukung dan membantu selama pelaksanaan penelitian. Penelitian ini dibiayai oleh Kementerian Riset dan Teknologi melalui program Insentif Ristek Nasional (InSINAS) tahun 2012 dan 2013.

\section{DAFTAR ACUAN}

Anonim. (2014). Ecdysteroids scientific review on usage, dosage, and side effect. www. examine.com. Diakses tanggal 21 April 2014.

Dooley, P.C., Crouch, P.J., \& West, J.M. (2002). Free amino acids in claw and hemolympp from Australian freshwater crayfish at different stages of the molt cycle. Comp. Biochem. Physiol., 131 A, 625-637.

Dorrington, J.H. (1979). Pituitary and placental hormones. In Austin, C.R. \& Short, R.V. (Eds.), Reproduction in Mammals; 7 Mecanisms of hormone action. Cambridge University Press. Cambridge. Cambridge, p. 53-80.

Effendie. (1997). Metode biologi perikanan. Yayasan Dewi Sri. Bogor, $112 \mathrm{hlm}$.

Fattah, M.H. (1998). Pengaruh suplemen hormon 20-hidroksiekdison dan kolesterol dalam pakan buatan serta ablasi tangkai mata terhadap sinkronisasi percepatan pelunakan karapaks dan pematangan telur kepiting bakau, Scylla serrata (FORSKAL, 1775). Disertasi. Program Pascasarjana. Institut Pertanian Bogor. Bogor.

Fujaya, Y. (2008). Kepiting Komersil Di Dunia, Biologi, Pemanfaatan, dan Pengelolaannya. Citra Emulsi. Makassar.

Fujaya, Y., Suryati, E., Nurcahyono, E., \& Nur, A. (2008). Titer ekdisteroid hemolimp dan ciri morfologi rajungan (Portunus pelagicus) selama fase moulting dan reproduksi. Torani, 18(3), 266-274.

Fujaya, Y., Aslamyah, S., Fudjaya, L., Alam, N. (2012). Budidaya dan bisnis kepiting lunak. Stimulasi Molting dengan ekstrak bayam. Brillian International Surabaya. 109 hal.

Gimenez, A.V.F., Garcia-Carreno, F.L., Navarette del Torro, M.A., \& Fenucci, J.L. (2001). Digestive proteinases of red shrimp Pleoticus muelleri 9 Decapoda, Penaeoidea): partial characterization and relationship with moulting. Comp. Biochem. Physiol., 130A, 331-338.

Gunamalai, V., Kirubagaran, R., \& Subramoniam, T. (2003). Sequesration of ecdisteroid hormone into the ovary of the mole crab, emerita asitica. (Milne Edwards). Currents Science, 85(4), 493-496.

Harborn, J.D. (1973). Phytochemical methods. Chapman and Hill. London, 354 pp.

Herlinah, Widodo, A.F., Suryati, E., Rachmansyah, Septiningsih, E., \& Tenriulo, A. (2012). Uji efektifitas hormon ecdysteroid dari ekstrak daun murbei, Morus spp. sebagai moulting stimulan pada produksi kepiting cangkang lunak. Laporan Akhir. Balai Penelitian dan Pengembangan Budidaya Air Payau. Maros (Unpublish).

Herlinah, Suryati, E., Syah, R., Tenriulo, A., Suryanto, H., Septiningsih, E., Kamaruddin, Syakaria, M., Tamsi, dan Mujayana. (2013). Efektifitas hormon ecdysterone dari ekstrak daun murbei dalam moist pelet untuk produksi kepiting bakau cangkang lunak. Laporan Akhir Intensif Riset SINas. RT-20131367. Balai Penelitian dan Pengembangan Budidaya Air Payau, Maros (unpublish).

Herlinah, Risal, M., Tenriulo, A., Septiningsih, E., \& Suwoyon, H.S. (2014). Respons moulting dan kelulusan hidup kepiting bakau (Scylla olivacea) yang diinjeksi dengan ekstrak daun murbei (Morus sp.). Balai Penelitian dan Pengembangan Budidaya Air 
Payau, Maros (unpublish).

Kim, S.Y., Gao, J.J., \& Kang H.K. (2000). Two flavonoids from the leaves of Morus alba induce differentiation of the human promyelocytic leukemia (HL-60) cell line. Biology Pharmacy Bulletine, 23(4), 451-5.

Lafont, R., \& Dinan, L. (2003). Practical uses for ecdysteroids in mammals including humans: an update. Available online: insectscience.org/3.7. Journal of Insect Science, $30 \mathrm{pp}$.

Louden, D., Handley, A., Taylor, S., Lenz, E., Miller, S., Wilson, D., Sage, A., \& Lafont, R. (2001). Spectroscopic characterisation and identification of ecdysteroids using high-performance liquid chromatography combined with 1 on-line UV-diode array, FT-infrared and H-nuclear magnetic resonance spectroscopy and time of flight mass spectrometry. Journal of Chromatography A, 910, 237-246.

Munson, J.W. (1984). Pharmaceutical analysis modern method. Part B. Marcel Dekker. Inc. The Upjohn Company. Kalamazoo. Michigan, $417 \mathrm{pp}$.
Quinitio, E.T., Yamauchi, K., Hara, A., \& Fuji, A. (1991). Profiles of progesterone and estradiol like substances in the hemolymph of female Pandalus kessleri during an annual reproductive cycle. Gen. Comp. Endocrinol., 81, 343-348.

Sanchez, M.D. (2000). World distribution and utilization of mulberry, potential for animal feeding. In FAO Electronic Conference on "Mulberry for Animal Production". http://www.fao.org/WAICENT/FAOINFO/ AGRICULT/AGA/AGAP/FRG/Mulberry/Papers/HTML/Intro.htm, Diakses Oktober 2011.

Steenis, C.G.G.J. (1981). Flora untuk sekolah di Indonesia. Cetakan ke-3. PT Pradnya Paramita, $949 \mathrm{hlm}$.

Suryati, E., Tenriulo, A., \& Tonnek, S. (2013). Pengaruh pemberian ekstrak pakis sebagai moulting stimulan pada induk udang windu (Penaeus monodon Fab.) di hatcheri. J. Ris. Akuakultur, 8(2), 221-228.

Turner, C.D., \& Bagnara, J.T. (1998). Endokrinologi umum. Jogjakarta. Airlangga University Press. 